\title{
Dividend Valuation, Trading and Transactions Costs: the 1997 Partial Abolition of Dividend Tax Credit Repayments
}

\author{
Paper number 04/08
}

\author{
Lynn Hodgkinson \\ University of Wales, Bangor \\ Kevin Holland \\ University of Wales, Aberystwyth \\ Richard H G Jackson* \\ University of Exeter
}

\begin{abstract}
Although in July 1997 UK resident tax-exempt shareholders lost the right to repayment of tax credits on dividends paid by UK resident companies, they could continue to receive tax credit repayments in respect of dividends received from Irish resident companies - many of which are listed on the London Stock Exchange. In July 1997 the rate of tax credit on Irish companies' dividends was 21\%. This was reduced to 11\% in December 1997, and the right to tax credit repayments was abolished in January 1999.
\end{abstract}

We obtain insights into the incentives and behaviour of tax-exempt investors in response to these changes in the relative 'tax attractiveness' of investments in Irish resident companies over UK resident companies. In particular, we examine the trade off between the availability of dividend tax credit repayment and the sum of transaction costs and portfolio restructuring costs. In addition, we examine the behaviour of stock price and trading volume of UK resident companies' stocks around ex-dividend days in order to provide a basis of comparison to, and to extend, the work of Bell and Jenkinson (2002).

We conclude as follows: (i) only at its highest rate, $21 \%$, was the level of dividend tax credit on Irish companies' dividends sufficient to induce changes in UK tax-exempt shareholders' investment strategies; (ii) implied total expected investor costs in dividend capture are in the order of $2.6 \%$, consistent with the costing of uncertainty over ex-dividend price and the efficacy of anti-avoidance legislation; (iii) tax-exempt shareholders were the marginal investors in UK resident companies prior to the July 1997, consistent with the findings of Bell and Jenkinson (2002); and (iv) tax induced dividend capture of UK companies' dividends is evidenced in trading volume patterns.

\section{Acknowledgement}

The authors would like to thank seminar participants at the Universities of Aston, Liverpool and Sydney and conference delegates at the British Accounting Association Annual Conference 2003, Manchester for their helpful comments and suggestions, and a former international tax partner of a 'Big 4' accountancy firm for assistance in interpreting relevant legislation.

\footnotetext{
*Contact Author: Richard Jackson Senior Lecturer in Accounting and Finance, School of Business and Economics, Streatham Court, Rennes Drive, University of Exeter, Exeter EX4 4PU. Tel +44 1392 263216, Secretary +44 1392 263201, Fax +44 1392 263210. E-mail: richard.jackson@exeter.ac.uk
} 
ISSN 14732904 


\section{Introduction}

The payment of dividends represents an important, predictable interaction between companies and shareholders. Numerous effects or 'non-effects' have been attributed to dividend policy. Modigliani and Miller (1963) demonstrate that, under certain market assumptions, firm value is independent of dividend policy, though unanticipated changes can impose tax and adjustment costs on shareholders. Conversely, in a setting characterised by information asymmetry between mangers and shareholders, dividend policy can increase firm value by reducing agency costs (Rozeff, 1982) and revealing managers' inside information to the capital markets (Ross, 1977). Other value relevant effects have been attributed to differential investor level marginal tax rates as between dividend income and realised gains, and to tick size, settlement costs, uncertainty in ex-dividend prices and market microstructure. These effects are not wholly mutually exclusive and, therefore, one or more of them can interfere in and confound attempts to examine any other in isolation. For example, a hypothesised tax-induced effect may not occur because of the existences of transaction costs, or the cumulation of a number of tax changes which are together sufficient to overcome transactions costs may give rise to spurious empirical detection and value overstatement in respect of one of the changes.

In a market valuation context, investor level tax considerations are only important when they impose costs or benefits on the 'price setting' or marginal shareholder and, therefore, influence their pricing decisions. In the UK, institutional investors dominate the London Stock Exchange (LSE) in terms of the volume and value of shares owned and traded; and, more importantly, tax-exempt institutional investors dominate in terms of price setting (Bell and Jenkinson, 2002).

This paper investigates a change in the dividend-related cash flows accruing to tax-exempt institutional investors. Although the UK Finance (No.2) Act 1997 abolished the right of UK resident tax exempt shareholders to claim repayment of tax credits on dividends received from UK resident companies on or after $2^{\text {nd }}$ July 1997, such shareholders could continue to receive tax credit repayments on a sub-group of UK listed companies. Under the terms of the UK - Republic of Ireland Double Taxation Convention in operation as at July 1997, tax exempt UK pension funds and UK insurance company tax exempt pension businesses (together hereafter referred to as 'TEPIC investors') continued to obtain tax credit repayments on dividends received from companies resident in the Republic of Ireland - many of which were (and, indeed, still are) listed on the London Stock Exchange. ${ }^{1,2}$ This state of affairs continued only until $31^{\text {st }}$ December 1998 , the double taxation

\footnotetext{
${ }^{1}$ Similarly, under Irish domestic legislation, Irish resident pension funds could also obtain repayments of tax credits from Irish resident companies. The general repayment of dividend tax credits to tax exempt investors was abolished from Irish domestic legislation in April 1999.

${ }^{2}$ The Irish Stock Exchange Ltd was established following the December 1995 demerger of The International Stock Exchange of the United Kingdom and the Republic of Ireland Ltd. Until that point, most Irish companies had dual listing on the Dublin and London Stock Exchanges (Mulligan, 1996). In order to alleviate the 'market
} 
convention having been revised by an amending protocol dated $4^{\text {th }}$ November 1998. Consequently, three tax regimes can be identified as follows:

(i) prior to $2^{\text {nd }}$ July 1997 TEPIC investors in both UK resident and Irish resident companies were entitled to the repayment of tax credits;

(ii) between $2^{\text {nd }}$ July 1997 and $31^{\text {st }}$ December 1998 TEPIC investors were entitled to the repayment of tax credits on dividends received only from Irish resident companies (an Irish dividend tax credit rate change during this period allows it to be further sub-divided into the periods $2^{\text {nd }}$ July 1997 to $2^{\text {nd }}$ December 1997, inclusive, and $3^{\text {rd }}$ December 1997 to $31^{\text {st }}$ December 1998, inclusive); and

(iii) after the $1^{\text {st }}$ January 1999 TEPIC investors were not entitled to a repayment of tax credit upon dividend from either UK resident or Irish resident companies.

Observing changes in investor behaviour as between the above periods can provide insights into investor incentives, expectations and attitudes concerning dividends. In order to abstract from signalling and agency considerations we examine 'ex-dividend' day price and volume changes, developing and testing a number of hypotheses concerning stock price and trading volume changes in response to variations in the availability and level of dividend tax credit repayments. These hypotheses link the relative 'tax attractiveness' of investment in Irish resident (as compared to UK resident) companies over the periods set out above and the actions of TEPIC investors, and are designed to obtain insights into the incentives to and behaviours of such investors. In particular, we examine the trade off between the availability of dividend tax credit repayment and transaction costs. Further, we examine the behaviour of stock price and trading volume of UK resident companies' stocks around ex-dividend days in order to provide a basis of comparison and to extend the work of Bell and Jenkinson.

The paper's main contributions can be summarised as follows: (i) the development and testing of taxbased hypotheses over a period containing several taxation changes; (ii) the examination of trading volume across a number of periods where there are clear variations in the expected profitability of dividend capture trading; and (iii) the development of a model which can explain the propensity of dividend capture trading activity in terms of transaction costs. The potential for impact of

presence' concerns of some Irish companies a 'special association agreement' allowed dual resident companies the option to maintain their dual listing status - and many of the larger Irish companies continue to hold such dual listing status (Lucey, 2001). Irish firms seeking an initial quotation post December 1995, however, had to choose between the two markets. 
confounding, unrelated changes to market and trading arrangements is mitigated in that the period over which the dividend taxation changes considered in the paper occurred, and, therefore, the sample period, are relatively short.

Our results can be summarised as follows. First, TEPIC investors appear to be the marginal investors in Irish resident shares only during the period when Irish dividend tax credit repayments were available at the rate of $21 \%$ (as compared to zero per cent for dividends from UK resident companies). This result is consistent with changes in the relative rates of tax credit repayment between UK and Irish resident companies inducing a change in TEPIC investors' strategies, i.e., evidence of a dividend clientele forming and subsequently dissipating. Second, the absence of evidence suggesting TEPIC investors where the marginal investors in Irish resident shares when Irish dividend tax credit repayments were available at the rate of only $11 \%$ (again, as compared to zero per cent for UK resident companies) is consistent with TEPIC investors' transaction costs being of sufficient magnitude to outweigh the now reduced potential tax benefits of holding shares of Irish resident companies, and with such investors seeking to maximise after tax returns rather than tax benefits. Third, our model of transaction and portfolio restructuring costs imply expected transaction costs in the order of $2.6 \%$ which is higher than the 'round trip' transactions costs suggested by James (2000). This finding is consistent with the expected costs of deviation from an otherwise optimal portfolio for the purposes of dividend (and related tax credit) capture being significant, uncertainty over exdividend price and the efficacy of anti-avoidance legislation which imposes additional costs by requiring a minimum holding period if dividend tax credit capture to be fully effective. Fourth, for UK resident companies, TEPIC investors appear to be the marginal investor prior to the abolition of tax credit repayments - consistent with the findings of Bell and Jenkinson. Fifth, we observe patterns in trading volume consistent with tax induced dividend capture for the UK resident companies (but data considerations prevent a similar analysis for Irish resident companies).

This remainder of this paper proceeds as follows: the next section discusses the relevant legislation and illustrates the impact of the changes on the taxation of dividends; previous work examining both price changes and volumes traded around the ex-dividend day are discussed in the third section; the fourth section sets out methodology, hypotheses, data source, definition of variables; the results are presented and discussed in the fifth section; and the final section concludes. 


\section{Relevant legislation}

This section summarises the relevant tax legislation covering the repayment of dividend tax credit and related anti-avoidance legislation in the context of the UK - Republic of Ireland Double Taxation Convention.

During the early part of the period under review, the Republic of Ireland and the United Kingdom both operated a partial imputation system regulating the interaction of the corporate and personal tax systems with respect to dividends. The key features of both countries' systems were identical. ${ }^{3}$ A company paying a (net) dividend was required to pay advance corporation tax (ACT) to the Inland Revenue/Revenue equal to the product of the lower rate of income tax and the gross dividend, where the gross dividend is equal to the net dividend plus the ACT. Shareholders received the net dividend plus an imputed tax credit ('tax credit') which together equalled the gross dividend. If the shareholder's marginal tax rate on dividend income ('marginal rate') was equal to the lower or basic rate of income tax, no further action was required. If the shareholder's marginal rate was greater than the lower rate, an additional payment, by the shareholder, was due to the tax authorities - being equal to the amount of the gross dividend multiplied by the excess of the higher rate over the basic rate. If, on the other hand, the shareholder's marginal rate was less than the lower rate of tax they could obtain a repayment equal to the amount of the gross dividend multiplied by the difference between their marginal rate and the lower rate of tax. Hence, a tax-exempt investor could reclaim an amount equivalent to the dividend tax credit in full.

After $1^{\text {st }}$ July 1997, however, the right of TEPIC investors to obtain repayment of the tax credit on dividends received from UK resident companies was abolished. The ability of tax-exempt investors resident in Ireland to obtain repayment of the tax credit on dividends received from companies resident in the Republic of Ireland continued until the abolition of dividend tax credits in April 1999. Intriguingly, though, during the period $2^{\text {nd }}$ July 1997 to $31^{\text {st }}$ December 1998, TEPIC investors could continue to obtain repayment of the tax credits on dividends paid by companies resident in the Republic of Ireland, under the terms of the UK - Republic of Ireland Double Taxation Convention then in operation (although no similar right existed under UK domestic legislation). One objective of taxation conventions is the avoidance of discrimination between taxpayers of the two contracting states. Post July 1997, Irish domestic legislation continued to allow repayment of tax credits on dividends from companies resident in the Republic of Ireland to tax exempt investors similarly

\footnotetext{
${ }^{3}$ This version of the UK imputation system was abolished by the Finance Act of 1999 with effect from 6 April 1999.
} 
resident. The convention extended that right to TEPIC investing in those same Republic of Ireland companies - thereby ensuring comparable treatment. ${ }^{4}$

The availability of tax credit repayments to tax exempt shareholders may generate a preference for dividend income over capital growth. ${ }^{5}$ Indeed, one of the justifications of the July 1997 change in the UK was to relieve the pressure on companies to pay dividends in order to satisfy the preferences of tax-exempt shareholders: 'The present system of tax credits encourages companies to pay out dividends rather than reinvest their profits' (Chancellor of the Exchequer, 1997). If non-tax factors lead tax-exempt shareholders to hold low dividend yield portfolios, such shareholders may attempt to increase dividend income by temporarily altering their portfolios to include higher dividend yielding shares. For example, purchasing and then selling a high dividend yield share around its ex-dividend date would provide additional dividend income whilst minimising the costs of temporary portfolio imbalance. Anti-avoidance legislation, however, exists in both the Republic of Ireland and the United Kingdom designed to thwart the tax benefit of such 'bond washing' activities. ${ }^{6,7}$ When a tax-exempt investor purchases a share and within a month and sells it (both transactions being at 'current market price'), and during the period of ownership the share turns ex-dividend, then the amount of available tax credit repayment is reduced by 'an appropriate amount'. ${ }^{8}$ This legislation, however, was in place in both the Republic of Ireland and the United Kingdom throughout the period under examination in this paper and, therefore, does not affect the relative 'tax attractiveness' of dividend income during the three phases of the identified natural experiment.

\footnotetext{
${ }^{4}$ The entitlement to repayment was given by paragraph 2(b), which originally read as follows: 'A resident of a Contracting State who receives dividends from a company which is a resident of the other Contracting State shall, subject to the provisions of sub-paragraph (c) of this paragraph and provided he is the beneficial owner of the dividends, be entitled to the tax credit in respect thereof to which an individual resident in that other Contracting State would have been entitled had he received those dividends, and to the payment of any excess of that tax credit over his liability to tax in that other Contracting State.' Sub-paragraph (c) referred to above provides that the entitlement to repayment is not available where the beneficial owner controls $10 \%$ or more of the voting power in the company paying the dividend. In the amended treaty, the original paragraph 2 was deleted.

${ }^{5}$ There may be non-tax reasons for such a preference. For example, Section 34 of the Pensions Act 1995 empowers trustees to make investments, but the Act does not define the term 'investment'. Case law provides some clarification, although there is still uncertainty. In Re Wragg (1919) 2 Ch. 55 p.64, 'investment' is defined narrowly as the purchase of property 'in order to be held for the sake of the income it will yield' (presumably in contrast to trading where the motive may be to purchase an asset with the expectation of a subsequent resale at a higher price). Although the courts have recognised new approaches to investment 'putting the emphasis in investment on the making of capital profit at the expense of investment yield' (Marson v. Morton [1986] 1 WLR 1343 at page 1350) the 'cautious approach must be to adopt the strict interpretation set out in Re Wragg in the absence of a more definite definition' (Nabarro Nathanson, 2000).

${ }^{6}$ The term 'bond washing' is generic to all activities that attempt to 'wash' an underlying security free of the related coupon or dividend payment.

${ }^{7}$ In the Republic of Ireland, the legislation is contained in Section 750 of the Taxes Consolidation Act 1997. The corresponding provisions in the United Kingdom are found in Section 733 of the Income and Corporation Taxes Act 1988.

${ }^{8}$ The reduction being given by:

max. potential tax credit $\times \frac{\text { period from previous ex - dividend date to one day before date of purchase }}{\text { period from previous ex - dividend date to 'current' ex - dividend date }}$
} 
The tax credit rates applicable to dividends from both Republic of Ireland resident and United Kingdom resident companies varied over the period under review and are set out in Panel A of Table 1. Panel B of Table 1 summarises the periods of availability of tax credit repayment to tax-exempt investors, as discussed above.

\section{Previous literature}

\subsection{Ex-dividend price behaviour}

In addition to the amount of dividend, a number of other factors have been identified in the literature as potentially influencing the level of the ex-dividend day fall in share price. In a risk-neutral world without taxes, and abstracting from transaction costs, settlement costs and other market imperfections, the drop in share price when a share turns ex-dividend should equal the dividend paid to shareholders. In other words, the ratio of the price drop to the dividend paid, often referred to as the drop off ratio (DOR), should be equal to one. Following the seminal work of Campbell and Beranek (1955), many empirical studies have examined whether or not this hypothesis holds. Elton and Gruber (1970) report that the price drop is more often than not less than the dividend paid and argue that the DOR will only be equal to one if the effective tax rates on dividends and capital gains are the same. They argue that shareholders can choose to sell a share when it is cum-dividend and forego the dividend payment, generating the following cash flows:

$$
P_{t-1}-T_{G}\left(P_{t-1}-P_{p}\right)
$$

where the ex-dividend date of the share is at time $t ; P_{t-1}$ is the share price at close on the trading day before $t ; P_{p}$ is the price originally paid for the share; and $T_{G}$ is the rate of taxation on capital gains which the investor faces.

Alternatively, the shareholder may choose to sell the share when it is ex-dividend and generate cash flows, under an imputation system, as follows:

$$
P_{t}-T_{G}\left(P_{t}-P_{p}\right)+D \frac{\left(1-T_{I}\right)}{\left(1-T_{A C T}\right)}
$$


where $P_{t}$ is the share price on the ex-dividend day; $D$ is the amount of dividend paid, $T_{I}$ is the rate of taxation on dividend income and $T_{A C T}$ is the rate of imputation tax (equal to the basic rate of tax during the period analysed). Investors will be indifferent between selling cum- or ex-dividend provided expressions (1) and (2) are equal. Assuming this condition, and rearranging the resulting equation, the DOR is given by:

$$
\frac{\left(P_{t-1}-P_{t}\right)}{D}=\frac{\left(1-T_{I}\right)}{\left(1-T_{G}\right)\left(1-T_{A C T}\right)}
$$

and, hence, the DOR will equal one if and only if $T_{I}=T_{G}+T_{A C T}-T_{G} T_{A C T}$. Under a classical tax system, such as that in the US, the DOR will equal one if and only if $T_{I}=T_{G}$.

Lakonsihok and Vermaelen (1983), Eades et al. (1984), Poterba and Summers (1984), Kaplanis (1986), Barclay (1987), Fedenia and Grammatikos (1993) and Lasfer (1995), amongst others, also suggest that differential taxation may explain a DOR of less than one. If investors' tax rates are not homogenous, however, arbitrage may occur as investors with relatively favourable income tax rates purchase shares cum-dividend from investors who face heavier income tax rates. If this arbitrage occurs the DOR will, in part, reflect the transaction costs of these short-term investors.

Other posited explanations for DORs different from one include tick size, settlement costs, uncertainty in ex-dividend prices and market microstructure effects. Bali and Hite (1998) argue that if the dividend payment is not a multiple of the current tick size, then the share price cannot change by the exact amount of the dividend and contend that the ex-dividend price fall will be rounded down to the nearest tick size, tending to deflate the DOR. Lasfer (1995) points out that prior to July 1994 the London Stock Exchange operated a fixed-settlement system under which investors, if they purchased shares at the start of the settlement period, did not have to settle for two weeks. A large proportion of shares tended to go ex-dividend on the first day of the settlement period, hence if an investor purchased a share cum-dividend (at the end of the previous settlement period) they would settle two weeks earlier than if they were to purchase the share ex-dividend. Frank and Jaganathan (1998) examine ex-dividend day pricing in Hong Kong, where neither dividends nor capital gains are taxed, and still find that the DOR ratio tends to be less than one, positing market microstructure as an explanation.

Under the imputation system, tax-exempt investors able to reclaim imputed tax credits upon dividends should prefer dividends to capital gains - and hence, we argue that the DOR (based on the net 
dividend), if such tax-exempt investors are the marginal investors and abstracting from all non-tax imperfections, should be greater than one.

\subsection{Tax-exempt investors}

The prominence of tax-exempt investors, and particularly pension funds, is evidenced by the significance of their aggregate holdings $(22.1 \%$ of total UK traded equity was held by pension funds as at $31^{\text {st }}$ December, 1997). The results of Bell and Jenkinson support the hypothesis that tax-exempt investors are the marginal investors in UK stocks, especially stocks with high dividend yield. Absent transactions costs and portfolio adjustment considerations, we would expect increased activity by TEPIC investors switching from UK resident to Irish resident stocks during the period $2^{\text {nd }}$ July 1997 to the $31^{\text {st }}$ December 1998, since, to this investor group over this period, dividends paid by Irish resident companies would be worth more than dividends paid by UK resident companies. Further, if TEPIC investors were the marginal investors in Irish resident stocks throughout the period, a significant decrease in the value of the dividend, i.e. a fall in the DOR, should be observed following the abolition of the tax credit on dividends from Irish resident companies.

Switches in investor holdings performed in order to capture the taxation-based benefits need only have been temporary, since TEPIC investors would only need to hold shares in the Irish resident company for a month including the date when they went ex-dividend in order to capture differential benefit in full (i.e., not reduced by anti-avoidance, 'anti-bond washing' legislation). A change in portfolio to capture these tax effects may, however, have required investors to deviate from their optimal portfolio, hence, potentially increasing their exposure to risk, ceteris paribus. This switch may only have been temporary, but since the price at which the investor could sell ex-dividend (at a point a month or more since purchase in order to enjoy the full differential benefit) was uncertain, the risk involved was further increased. Trading also, as always, would have incurred transactions costs. Hence, rational investors would only have traded to capture dividends if the expected differential taxation-based benefits exceeded the expected costs of additional risk and transaction costs involved.

\subsection{Ex-dividend trading volume}

Michaely and Vila (1995) posit that examining ex-dividend pricing alone may be insufficient to identify investors' tax preferences and suggest that changes in trading volume around the ex-dividend day may provide further information beyond that contained in prices. They argue that it is not possible to identify from prices whether investors face homogenous or heterogenous effective tax rates, and suggest that trading volume increases significantly around the ex-dividend day, reflecting 'dividend capture', and that it will increase further as investors face increasingly different preferences for 
dividends or capital gains. Both transaction costs and potential increases in risk (due to temporarily moving from an optimal portfolio) are unavoidable costs involved in switching shares to capture tax credits. As discussed above, if the expected costs of switching outweigh the potential benefits investors will not trade, and hence the higher the transactions costs and the increase in systematic risk, the less attractive dividend capture becomes. Michaely and Vila (1995) find that both transaction costs and risk significantly impact on the volume of shares traded around the ex-dividend day, whereas their impact on prices is found, by these authors, to be less significant.

Li (2002) reports that excess trading volume increases with dividend yield. Li also examines the impact of different tax regimes and argues that 'tax regime changes should have an impact on exdividend excess trading volume because they cause changes in the relative taxation of dividends and capital gains' and goes on to say 'the gains to exchanging tax burdens among investors with different tax status increases [decreases] and this increases [decreases] trading volume around the ex-dividend days.' The difference between the effective tax rates for dividends and capital gains increased in the US following an increase in income tax rates in 1993 and a decrease in capital gains tax rates in 1997. $\mathrm{Li}$ expected to find an accompanying increase in trading volume reflecting the increased potential for tax arbitrage but, instead, found a decrease. He contends that this may be due to a decrease in dividend yield, suggesting firms may have changed their dividend policy following the tax regime changes.

The removal of the tax credits, first in the United Kingdom and then in the Republic of Ireland, decreased the extent of differential taxation between capital gains and dividends over time. The decrease in potential benefits was likely to discourage the extent of dividend capture activity following the removal of the tax credits, and hence it is expected that the extent of excess trading volume around the ex-dividend day has on the whole decreased over the periods examined.

Foregoing discussion concerning trading volume around ex-dividend days must be compounded by consideration of the effects of applicable anti-avoidance legislation. As set out in Section 2, such legislation was in operation in both the Republic of Ireland and the UK throughout the period of this study - denying full repayment of dividend tax credit (where available) to investors if they did not hold the underlying share for one month or more. For example, purchase of a share on its last day cum-dividend and sale on the ex-dividend date would result, assuming successful operation of the anti avoidance legislation, in a very small proportion of the associated dividend tax credit to be reclaimed. 


\section{Methodology, hypotheses, data source, variables and models}

We examine the market valuation of dividends and trading volumes around ex-dividend regimes for UK and Irish companies quoted on the London Stock Exchange over the following four tax regimes:

i) Prior to the $2^{\text {nd }}$ July 1997 - when TEPIC investors in both UK and Irish resident companies were able to reclaim the tax credit associated with those companies' dividends. In the following, this period is designated period 'Both'.

ii) From $2^{\text {nd }}$ July 1997 to $2^{\text {nd }}$ December 1997 (inclusive) - when TEPIC investors were able to reclaim the tax credit associated with dividends from Irish resident companies at a rate of $21 \%$ on the gross dividend, but were unable to make any such claim in respect of dividends from UK resident companies. This period is designated 'Irish21'.

iii) From $3^{\text {rd }}$ December 1997 to $31^{\text {st }}$ December 1998 (inclusive) - when TEPIC investors were able to reclaim the tax credit associated with dividends from Irish resident companies at a rate of $11 \%$ on the gross dividend, but were unable to make any such claim in respect of dividends from UK resident companies. This period is designated 'Irish11'.

iv) Following $31^{\text {st }}$ December 1998 - when TEPIC investors were not able to reclaim any tax credit in respect of dividends paid by either UK or Irish resident companies. This period is designated 'Neither'.

\subsection{Price behaviour}

This sub-section commences with the formulation of regression models to explain ex-dividend price behaviour. We formulate two primary regression models in respect of each of Irish and UK resident companies' dividend events - an unscaled and a scaled model - and in each case perform the estimations using both unadjusted and market-adjusted prices. The section goes on to formulate hypotheses concerning the models' coefficients.

In line with Elton and Gruber (1970) we compare the drop in share price on the ex-dividend day with the net dividend paid as follows:

$$
\frac{P_{i, t-1}-P_{i, t}}{D_{i, t}}
$$


where, for company $i$ going ex-dividend at time $t, P_{i, t-1}$ and $P_{i, t}$ are, respectively, the closing prices per share on the cum-dividend and ex-dividend days, and $D_{i, t}$ is the net dividend per share paid.

If the drop in share price is equal to the net dividend paid, the DOR, as per expression (4), will equal 1. The DOR, in effect, indicates the value of the dividend to the marginal investor in the stock. If dividends are tax-advantaged to capital gains, which, indeed, they were for TEPIC investors up to $2^{\text {nd }}$ July 1997 in respect of both UK and Irish resident stocks, and further up to $31^{\text {st }}$ December 1998 in respect of Irish resident stocks, and TEPIC investors are the marginal investors, we would expect the DOR to be greater than one during the periods of tax-advantage. ${ }^{9}$ Although we report the DORs, there are methodological problems with the statistic as it is not normally distributed and is distorted by very small net dividend payments. An alternative procedure to identify the relationship between the price drop and the dividend is to examine the slope coefficient, $\beta_{i}$, in the following regression:

$$
P_{i, t-1}-P_{i, t}=\beta_{i} D_{i, t}+\varepsilon_{i}
$$

where $\varepsilon_{i}$ is a stochastic error term.

Following Frank and Jaganathan (1998), who argue that a significantly negative intercept is evidence of a market-microstructure effect, we allow for an intercept as follows:

$$
P_{i, t-1}-P_{i, t}=\alpha+\beta D_{i, t}+\varepsilon_{i}
$$

Finally, in order to examine whether or not the market value of dividends has changed over the three periods of our study (periods Both, Irish and Neither) we include period slope dummies and estimate, via OLS, the following augmented model:

$$
\begin{aligned}
P_{i, t-1}- & P_{i, t}=\alpha+\beta D_{i, t}+\beta_{\text {BOTH }}\left(\text { BOTH } \cdot D_{i, t}\right) \\
& +\beta_{\text {IRISH } 21}\left(\text { IRISH } 21 \cdot D_{i, t}\right)+\beta_{\text {IRISH } 11}\left(\text { IRISH } 11 \cdot D_{i, t}\right)+\varepsilon_{i}
\end{aligned}
$$

where $B O T H$ is a zero-one dummy, equal to one when the ex-dividend day falls in the period prior to $2^{\text {nd }}$ July, 1997; IRISH21 is a zero-one dummy, equal to one when the ex-dividend day falls in the period from $2^{\text {nd }}$ July, 1997 to $2^{\text {nd }}$ December 1997 (inclusive); and IRISH11 is a zero-one dummy, equal

\footnotetext{
${ }^{9}$ Abstracting from other factors, as discussed earlier, which may affect the DOR.
} 
to one when the ex-dividend day falls in the period from $3^{\text {rd }}$ December 1997 to $31^{\text {st }}$ December 1998 (inclusive). The 'base case' of the model, is, therefore, for ex-dividend days falling in the period following the $31^{\text {st }}$ December 1998.

This estimation is performed separately for dividend events associated with Irish resident firms ("the unscaled Irish model') and those associated with UK resident firms ('the unscaled UK model'). In the UK model, there is no effect from changing rates of Irish dividend tax credit, so the estimated model is simplified to:

$$
\begin{aligned}
P_{i, t-1}-P_{i, t}=\alpha+\beta D_{i, t} & +\beta_{\text {ВОтH }}\left(\text { BOTH } \cdot D_{i, t}\right) \\
& +\beta_{\text {IRISH }}\left(\operatorname{IRISH} \cdot D_{i, t}\right)+\varepsilon_{i}
\end{aligned}
$$

where IRISH is a zero-one dummy, equal to one when the ex-dividend day falls in the period from $2^{\text {nd }}$ July, 1997 to $31^{\text {st }}$ December 1998 (inclusive). In discussing the UK data and the UK model, therefore, we designate 'period Irish' to be from $2^{\text {nd }}$ July 1997 to $31^{\text {st }}$ December 1998 - when TEPIC investors were able to reclaim the tax credit associated with dividends from Irish resident companies at a rate of either $21 \%$ or $11 \%$ on the gross dividend, but were unable to make any such claim in respect of dividends from UK resident companies.

We also estimated scaled forms of the above models to mitigate any heteroscedasticity concerns.

$$
\begin{aligned}
& \frac{P_{i, t-1}-P_{i, t}}{P_{i, t-1}}=\alpha+\beta \frac{D_{i, t}}{P_{i, t-1}}+\beta_{\text {ВОтH }}\left(\text { BOTH } \frac{D_{i, t}}{P_{i, t-1}}\right) \\
& +\beta_{\text {IRISH } 21}\left(\operatorname{IRISH} 21 \frac{D_{i, t}}{P_{i, t-1}}\right)+\beta_{\text {IRISH } 11}\left(\operatorname{IRISH} 11 \frac{D_{i, t}}{P_{i, t-1}}\right)+\varepsilon_{i}
\end{aligned}
$$

for dividend events associated with Irish resident firms ('the scaled Irish model'), and

$$
\begin{array}{r}
\frac{P_{i, t-1}-P_{i, t}}{P_{i, t-1}}=\alpha+\beta \frac{D_{i, t}}{P_{i, t-1}}+\beta_{\text {вотн }}\left(\text { BOTH } \frac{D_{i, t}}{P_{i, t-1}}\right) \\
+\beta_{\text {IRISH }}\left(\operatorname{IRISH} \frac{D_{i, t}}{P_{i, t-1}}\right)+\varepsilon_{i}
\end{array}
$$


for dividend events associated with UK resident firms ('the scaled UK model'), where, in each, the variables are as previously defined.

We estimate each of these models using both unadjusted and market-adjusted prices ${ }^{10}$, making the market adjustment as follows:

$$
P_{i, t}=P_{i, t}-P_{i, t-1} \beta_{i, t} R_{m, t}
$$

where $R_{m, t}$ is the return on the market on the ex-dividend day, as proxied by the return on the Financial Times All Shares Index, and $\beta_{i, t}$ is the equity beta of company $i$ as estimated using the market model and daily returns data over the -105 to -6 days prior to ex-dividend day $t$. Bell and Jenkinson use monthly returns in calculating equity betas, in order to overcome problems with thin trading, whereas we choose to adopt the Scholes-Williams (1977) adjustment. In order to use monthly data to compute the equity beta it is necessary to use returns from a considerably longer period than is the case if daily returns are used - over which longer period there is greater chance that the risk characteristics of the company may have changed and, hence, a greater chance that the equity beta may be biased.

If TEPIC investors in Irish resident stocks were the marginal investors during periods Both, Irish 21 and Irish 11, then we would expect each of $\beta_{B O T H}, \beta_{I R I S H 21}$ and $\beta_{I R I S H 11}$ to be significantly greater than zero in the Irish models (since the dividend would be worth significantly more to the tax-exempt pension fund investor prior to the removal of the tax-credit). If such investors were not normally the marginal investors in Irish resident firms, but were the marginal investors during the second and third periods (periods Irish21 and Irish 11) - when TEPIC investors could have been attracted to Irish resident companies in order to capture the tax-credit, which was no longer available in respect of UK resident companies, we would expect $\beta_{\text {IRISH } 21}$ and $\beta_{\text {IRISH } 11}$ to be significantly greater than zero, but not $\beta_{\text {BOTH }}$. If neither $\beta_{B O T H}, \beta_{\text {IRISH } 21}$ nor $\beta_{\text {IRISH } 11}$ are significantly different from zero, we would conclude that TEPIC investors did not take the opportunity to capture the tax credit by investing in Irish resident stocks and/or they were not the marginal investors at any time during the period under analysis. Finally, whether or not $\beta_{\text {BOTH }}$ is significantly greater than zero, if $\beta_{\text {IRISH } 21}$ is significantly greater than zero whilst $\beta_{\text {IRISH11 }}$ is not, we would conclude that TEPIC investors acted to capture dividends and associated tax credits during period Irish21, but not during Irish11; and, further, that

\footnotetext{
${ }^{10}$ We report the results based on market-adjusted prices in the next section. Results based on unadjusted prices are not qualitatively different for the Irish models. For the UK models, slight differences in results based on unadjusted prices in comparison to the main reported results are disclosed by way of footnote in the next section. Full results based on unadjusted prices are available from the authors.
} 
dividend capture was perceived to be worthwhile with a dividend tax credit rate of $21 \%$ on gross dividend, but not when the tax credit rate was $11 \%$ - i.e., we may deduce some bounds for total transactions and portfolio restructuring costs as expected by these investors.

If our results for the UK model are to support those of Bell and Jenkinson, we would deduce that taxexempt investors were the marginal investors in UK resident stocks and that $\beta_{\text {ВОтН }}$ should be significantly greater than zero (since the dividend would be worth significantly more to the TEPIC investor prior to the removal of the tax-credit). Further, the coefficient $\beta_{\text {IRISH }}$ should not be significantly greater than zero as TEPIC investors in UK resident stocks could not reclaim the taxcredit during period Irish.

Our hypotheses are, therefore, as follows:

Hypothesis 1. TEPIC investors were the marginal investors in Irish resident stocks quoted on the LSE prior to the removal of the tax credit for such stocks on the $3 I^{\text {st }}$ December 1998. As a result $\beta_{\text {BOTH }}, \beta_{\text {IRISH } 21}$ and $\beta_{\text {IRISH } 11}$ are all significantly greater than zero in the Irish models.

Hypothesis 2. TEPIC investors were the marginal investors in Irish resident stocks quoted on the LSE prior to the reduction in dividend tax credit rate for such stocks from $21 \%$ to $11 \%$ on $3^{\text {rd }}$ December 1997. As a result $\beta_{\text {BOTH }}$ and $\beta_{\text {IRISH } 21}$ are significantly greater than zero and $\beta_{\text {IRISH } 11}$ is not significantly greater than zeros.

Hypothesis 3. TEPIC investors were not normally the marginal investors in Irish resident stocks quoted on the LSE prior to $2^{\text {nd }}$ July 1997, but were the marginal investors during the period $2^{\text {nd }}$ July 1997 to $31^{\text {st }}$ December, 1998 in order to capture the preferential treatment, with respect to the tax credit, afforded to investment in Irish resident companies. As a result $\beta_{\text {IRISH } 21}$ and $\beta_{\text {IRISH } 11}$ are significantly greater than zero in the Irish models, but $\beta_{\text {Вотн }}$ is not.

Hypothesis 4. TEPIC investors were not normally the marginal investors in Irish resident stocks quoted on the LSE prior to $2^{\text {nd }}$ July 1997or after $2^{\text {nd }}$ December 1997, but were the marginal investors during the period $2^{\text {nd }}$ July 1997 to $2^{\text {nd }}$ December, 1997 in order to capture the preferential treatment, with respect to the tax credit at $21 \%$, afforded 
to investment in Irish resident companies. As a result $\beta_{\text {IRISH } 21}$ is significantly greater than zero in the Irish models, but $\beta_{\text {BOTH }}$ and $\beta_{\text {IRISH } 11}$ are not.

Hypothesis 5. TEPIC investors were the marginal investors in UK resident stocks quoted on the LSE prior to the removal of the tax credit for such investment on the $2^{\text {nd }}$ July 1997. As a result $\beta_{B O T H}$ is significantly greater than zero in the UK models, but $\beta_{\text {IRISH }}$ is not.

\subsection{Clustering}

To control for potential effects of UK resident companies' shares going ex-dividend on the same days, i.e., concern that residuals may not be independently and identically distributed, the UK model estimations were repeated using portfolios of stocks grouped on the basis of their ex-dividend day. The results do not differ substantially from those set out in the next section. Therefore, in the interests of economy, they are not separately reported in full, but differences from the main reported results are disclosed by way of footnote. ${ }^{11}$ Concerning dividend events of Irish registered companies, 70 of our sample of 98 events (71\%) occurred on days absent any other sample dividend events; and only 28 of our sample of events $(29 \%)$ occurred on days on which there was one or more other sample dividend event. Therefore, re-estimation of the Irish models to allow for clustering was not considered necessary.

\subsection{Trading behaviour}

As discussed above, trading volumes are expected to be higher around the ex-dividend day, as taxprivileged investors purchase the shares cum-dividend and sell ex-dividend. Similar to Michaely and Vila (1995) and Li (2002), we compute the excess trading volume on days -5 to +5 around the exdividend day, $E V_{i, t}$, as follows:

number of shares in stock $i$ traded on day $t$

$\overline{\text { average no. of shares in stock } i \text { traded per day during estimation period }}$

where $t \in[-5,+5]$ in terms of days relative to the ex-dividend day. We adopt an estimation period of -105 to -6 days relative to the ex-dividend day.

Partitioning the sample by Irish versus UK residence, and the Irish sample by four tax regime periods and the UK sample by three, we calculate average excess volumes as follows:

\footnotetext{
${ }^{11}$ These results are available from the authors.
} 


$$
\overline{E V}_{t}=\frac{1}{n_{t}} \sum_{i=1}^{n_{t}} E V_{i, t}
$$

where $t \in[-5,+5]$, relative to the ex-dividend day, and $n_{t}$ is the number of ex-dividend day observations during the tax regime concerned during 'relative' day $t$ during the test period.

We also calculate the significance with which we may infer that the mean trading volume during the test period exceeds that during the estimation period ( $t$-test on difference in means, one tailed test) for each dividend event, and, again partitioning the sample as above, calculate the proportions of each sub-sample in which such significance is below the $50 \%, 10 \%, 5 \%, 2.5 \%$ and $1 \%$ levels. We then compare proportions over tax regime of, separately, Irish and UK resident companies.

As the extent of tax-heterogeneity was greater for both Irish and UK resident stocks prior to the removal of the tax credit, we would expect excess trading to be greater during that period. In particular, during the period $2^{\text {nd }}$ July 1997 to $31^{\text {st }}$ December 1998 not only was there tax-heterogeneity based on investors' tax positions, but the ability of investors in Irish resident companies still to reclaim dividend tax credits meant there was tax-heterogeneity based on the residency of the companies. We would expect, as a result, that the volume of shares traded in Irish resident stocks to be greater during this period; and greatest, during the period $2^{\text {nd }}$ July 1997 to $2^{\text {nd }}$ December 1997 while the rate of Irish dividend tax credit remained at $21 \%$. Hence the following hypotheses:

Hypothesis 6. The number of shares traded in Irish resident stocks quoted on the LSE around dividend events was higher during the period prior to $2^{\text {nd }}$ July 1997 than it was after the $31^{\text {st }}$ December 1998, and highest during the period $2^{\text {nd }}$ July 1997 to the $31^{\text {st }}$ December, 1998 - consistent with TEPIC investors changing their portfolios in order to capture the preferential treatment with respect to the tax credit afforded to investors in Irish resident companies.

Hypothesis 7. The number of shares traded in Irish resident stocks quoted on the LSE around dividend events was higher during the period prior to $2^{\text {nd }}$ July 1997 than it was after 2nd December 1997, and highest during the period $2^{\text {nd }}$ July 1997 to $2^{\text {nd }}$ December, 1997 - consistent with TEPIC investors changing their portfolios in order to capture the preferential treatment with respect to the tax credit at $21 \%$ afforded to investors in Irish resident companies. 
Hypothesis 8. The number of shares traded in UK resident stocks quoted on the LSE around dividend events was higher prior to $2^{\text {nd }}$ July 1997 than it was after this date consistent with higher tax heterogeneity.

\subsection{Data}

The data source for this study was Datastream. Datastream list FTAL99 (list of FTSE All Share Index constituents in 1999) yielded 811 UK firms listed on the LSE in 1999; and Datastream list FLON (all non-UK-registered firms listed on the LSE) together with list DEADIR ('dead' Irish firms) yielded 57 Irish registered, LSE listed firms. Starting with the population of all these firms' dividend events during the period 1996 to 1999 (inclusive), reductions were made for 'unusable events' as per Table 2 to give a useable sample of 4,028 UK resident company dividend events and 193 Irish resident company dividend events with ex-dividend date during the period 1 January 1996 to 31 December 1999 for which share price data were available from 105 days prior to the ex-dividend date through to the ex-dividend date.

To avoid problems associated with thin trading of company shares, and following Bell and Jenkinson, who point out that although no price change is observed if there is no trade on the ex-dividend day the price might change when the share is traded later, it is appropriate to include in the DOR and regression analyses only dividend events where the stock was traded on the ex-dividend day. Therefore, we exclude dividend events where there was no share price change on the ex-dividend day. Finally, we exclude from the samples dividend events where the declaration and payment dates straddle changes in availability in dividend tax credit repayment to TEPIC investors, i.e. dividends declared by Irish or UK resident firms before $2^{\text {nd }}$ July 1997 and paid on or after that date, and dividends declared by Irish resident firms up to and including $31^{\text {st }}$ December 1998 and paid after that date. As per Table 2, this results in samples of 3,596 UK resident company dividend events and 98 Irish resident company dividend events for which analyses of basic statistics, DOR and regression estimation are performed.

Trading volumes data were also collected for the period 105 days prior to and 5 days following the exdividend day where such data were available from our Datastream source, yielding samples of 2,955 UK resident company dividend events and 70 Irish resident company dividend events for which analysis of trading volume is performed (see Table 2).

The number of Irish resident company dividend events in our sample is, therefore, modest, particularly in period Irish21, with potential implications for the level of significance of the relationships that we hypothesise and seek. It is important to note, however, that our samples are based on the population of 
all LSE-listed UK and Irish resident firms' dividend events with an ex-dividend date between 1 January 1996 and 31 December 1999, with sample reduction owing only to methodological necessity and data availability.

Since tax treatment of dividend and, in particular, availability and rate of associated tax credit reclaim, depend upon the date the dividend was paid (rather than, for example, the date it was declared or approved), our sample dividend events are assigned to periods (Both, Irish21, Irish11 or Neither for Irish resident companies' dividends, and Both, Irish or Neither for UK resident companies' dividend events) based on payment date.

\section{Empirical results}

\subsection{Basic statistics}

The basic statistics for the samples analysed are presented in Table 3. The mean DOR for Irish resident stocks (Table 3, Panel A) rises from 0.152 during period Both to 3.480 during period Irish21; then falls during period Irish11 to 0.177, a level similar to that seen in period Both; and finally rises in period Neither to 0.900 . This is consistent with our fourth hypothesis, that TEPIC investors were not normally the marginal investors in Irish resident stocks quoted on the UK Stock Exchange prior to $2^{\text {nd }}$ July 1997or after $2^{\text {nd }}$ December 1997, but were the marginal investors during the period $2^{\text {nd }}$ July 1997 to $2^{\text {nd }}$ December, 1997, in order to capture the preferential treatment, with respect to the tax credit at $21 \%$, afforded to investment in Irish resident companies. Testing the changes in DOR using both a parametric test (analysis of differences in means) and a non-parametric test (Wilcoxon Mann Whitney test) (Table 4, Panel A), we find strong support for this hypothesis. Under difference of means testing, the change between periods Both and Irish 21 is significant at the 5\% level; that between Irish $21^{12}$ and Irish 11 at 1\%; and the change between periods Irish 11 and Neither is not significant. The respective significances via Wilcoxon Mann Whitney testing are 1\%, 5\% and insignificant.

The mean DOR is greatest for UK resident companies (Table 3, Panel B) when the tax-credit is available, falling slightly from 0.774 in period Both to 0.763 in period Irish, and falling again to 0.435 in period Neither. This lends some support to our fifth hypothesis (above), although the fall in DOR between periods Both and Irish is lower than expected. Our results as between periods Both and Neither are in agreement with those of Bell and Jenkinson, who argue that, since the only group of investors affected by the removal of the tax credit were tax-exempt investors, a significant change in

\footnotetext{
${ }^{12}$ To determine whether the companies paying a dividend during the period Irish 21 accelerated their dividend payment to take advantage of the higher tax credit we compared the month in which the dividend was paid to the
} 
the DOR suggests that the marginal investors in UK resident companies were tax-exempt. The level of DOR during period Irish under this analysis, however, prevents a clear-cut conclusion. The methodological issues in using the 'raw' DOR are, however, as discussed above. We move on below to regression analysis as used to identify an implied DOR from slope coefficients.

\subsection{Regression analysis}

The results of the OLS estimations along with diagnostic statistics are summarised in Tables 5 and 6 . The residuals of the unscaled models (Table 5) and scaled models (Table 6) exhibit high levels of nonnormality. Non-normality in the distribution of the residuals can be as a result of non-normality in the dependent variable (Rawlings, 1988). In our data the main form of departure from non-normality is kurtosis, specifically the residuals are lepyokurtic or peaked. ${ }^{13}$ Whilst it can be argued that with a sufficiently large sample size this should not be a cause for concern, we assess the sensitivity of the reported results by employing a transformation of the dependent variable. In order to 'broaden' the distribution we employ a cube root transformation of the dependent variable (Rawlings, 1988). Though the Jarque-Bera statistic is still significant in two of the models, the transformation has the desired effect of significantly reducing the level of the diagnostic statistic in all four models. ${ }^{14}$ The reported Breusch-Pagan test statistics indicate significant departures from the assumption of homoscedastic variances in both the UK unscaled and scaled models, consequently, the reported tstatistics incorporate the White (1980) adjustment. The sensitivity of the models to the presences of influential observations has been assessed using the DEFITS statistic (Belsley, Kuh and Welsch, 1980), which suggests that the reported results are not sensitive to the inclusion of influential observations. $^{15}$

The results of estimation of the unscaled Irish and UK models are summarised in Table 5. The coefficient $\beta_{1}$, at 0.7759 , is significantly greater than 0 and is not significantly less than one. This coefficient represents the implied DOR in respect of UK resident companies' dividends in the model's

month the dividend was paid in the subsequent year. The same month was used for the payment of both dividends.

${ }^{13}$ For the sample of UK firms, kurtosis statistics of 135.230 and 24.273 occurred in the unscaled and scaled measures of the dependent variable respectively. The issue was less problematic in the Irish sample, where the corresponding figures were 2.573 and 5.952 respectively.

${ }^{14}$ The two significant test statistics occur: (i) in the unscaled Irish model (6.168 compared with 43.04 in the absence of the transformation); and (ii) in the scaled UK model (134.176 compared with $>77,363$ in the absence of the transformation). Since each of the four transformed models is qualitatively identical to its corresponding untransformed model, in the interests of economy we report only the untransformed models. Full results are available for the authors.

${ }^{15}$ Observations with a DEFITS statistics in excess of the critical level were excluded and the model reestimated. In each of the four models the results are qualitatively identical to those reported in Tables 5 and 6 and are not, therefore, reported separately. Full results are available from the authors. The critical value is calculated as $2 \times \sqrt{p / n}$, where $p$ is the number of independent variables plus one, and $n$ is the number of observations (Belsley et al., 1980). 
'base case', i.e., the period following removal of entitlement by TEPIC investors to tax credit repayment. Coefficient $\beta_{\text {BOTH }}$, at 0.4241 , is positive and significant, leading to an implied DOR of 1.200 (being the sum of coefficients $\beta_{1}$ and $\beta_{\text {ВOTH }}$ ) in respect of UK resident companies' dividend prior to the removal of the dividend tax credit. Coefficient $\beta_{\text {IRISH }}$ in this estimated model is positive, but insignificant. Although the sign of the intercept is negative as hypothesised, it is not statistically significant at accepted levels. The implied DOR at 1.200, greater than the 1.069 reported by Bell and Jenkinson for the large companies in their sample, is still below the theoretical figure of 1.25 which would be expected, absent transactions costs, during a period when the marginal investor was able to reclaim the tax credit and that rate of tax credit on gross dividend was $20 \%$ - as was the case during period Both. ${ }^{16}$ Overall, therefore, we deduce support for Hypothesis 5, i.e., that TEPIC investors were the marginal investors in UK resident stocks quoted on the LSE prior to the removal of the tax credit for such investment on the $2^{\text {nd }}$ July 1997

The results of the unscaled Irish model can be summarised as follows: the coefficient $\beta_{1}$ is significantly greater than zero, but not significantly less than one, and implies a DOR in respect of Irish resident companies' dividends of 0.7955 following removal of entitlement by TEPIC investors to tax credit repayment. Coefficients $\beta_{\text {ВотH }}$ and $\beta_{\text {IRISH } 11}$ are both negative but insignificant. Coefficient $\beta_{\text {IRISH } 21}$, at 2.1796 , is positive and significant, providing further support of Hypothesis 4 in confirmation of our results from analysis of 'basic statistics' above; and lending no support to alternative Hypotheses 1, 2 or 3, each of which requires at least one of $\beta_{\text {BOTH }}$ and $\beta_{\text {IRISH 11 }}$ to be positive and significant. The estimated intercept for the unscaled Irish model is of the expected (negative) sign, but is insignificant.

As reported in Table 6, estimation of the scaled UK model confirms the qualitative results from estimation of the unscaled UK model (above): the coefficient $\beta_{1}$ on net dividend at 0.8869 is both significantly greater than zero and significantly less than one, and is and is close to the DOR of 0.867 reported by Bell and Jenkinson for the largest 250 companies in their sample. Coefficient $\beta_{\text {ВОтH }}$, at 0.1003 is positive and significant. In this model the implied DOR is 0.967 (again, being the sum of coefficients $\beta_{1}$ and $\beta_{\text {BOTH }}$ ) in respect of UK resident companies' dividend prior to the removal of the

\footnotetext{
${ }^{16}$ Re-estimation of the unscaled UK model based on unadjusted (i.e., not market adjusted) prices gave qualitatively similar results. The only difference was coefficient $\beta_{\text {IRISH }}$ being significant at the $1 \%$ level (cf. not significant above). Re-estimation of the unscaled UK model to allow for clustering also gave qualitatively similar results. The only differences was coefficient $\beta_{\text {IRISH }}$ being significant at the $5 \%$ level (cf. not significant above).
} 
dividend tax credit. Coefficient $\beta_{\text {IRISH }}$, is not statistically significant at normally accepted levels; and the intercept is of the hypothesised (negative) sign and statistically significant implying the presence of market microstructure effects on ex-dividend prices. ${ }^{17}$ The scaled Irish model provides no explanatory power, (having an adjusted $R^{2}$ statistic of zero), however the lack of power is sensitive to the exclusion of influential observations. ${ }^{18}$

\subsection{Trading volume}

Michaely and Vila (1995) argue that trading volume is positively related to tax-induced heterogeneity in stock ownership. Prior to the removal of the tax credit, there was a higher degree of tax heterogeneity as dividends were of a substantially different value to tax-exempt investors than to others due to the tax credit. Therefore, we would expect a higher trading volume prior to the removal of the tax credit. If TEPIC investors, in order to capture a tax credit, were temporarily purchasing Irish resident stocks cum-dividend and then selling the stocks ex-dividend during the period $2^{\text {nd }}$ July 1997 to $31^{\text {st }}$ December 1998 (inclusive), we would expect to observe a high trading volume in such stocks over this period. Alternatively, if such dividend capture activity were restricted to the period when the dividend tax credit associated with Irish resident stocks' dividends was $21 \%$, we would expect to observe a high trading volume in the period $2^{\text {nd }}$ July 1997 to $2^{\text {nd }}$ December 1997 (inclusive) only. During these periods there was not only a high degree of tax heterogeneity among investors but also a high degree of tax heterogeneity among stocks. Hypotheses 6 and 7 (above) pertain. Similarly, in respect of UK resident stocks, Hypothesis 8 (above) predicts a higher trading volume before removal of the right of TEPIC investors to re-claim dividend tax credit.

For Irish resident stocks, Table 7 Panel A suggests that, contrary to expectations, although positive abnormal trading volume occurred during each of the periods, it was highest during period Neither and lowest during period Irish21. It was expected that the highest abnormal trading volume would occur prior to the removal of the tax credit (when there was a higher degree of tax-heterogeneity), whereas the highest abnormal trading volume actually occurred after the removal of the tax credit. Foregoing discussion of the net value of the differential tax treatment, subsuming transactions and portfolio adjustment costs, pertains. Li (2002) also reports results for the US which contradict expectations since highest excess trading volume occurred when tax heterogeneity was at its lowest. Also in line

\footnotetext{
${ }^{17}$ Re-estimation of the scaled UK model based on unadjusted (i.e., not market adjusted) prices gave qualitatively similar results. The only differences were: (i) coefficient $\beta_{\text {ВОтH }}$ was not significant (cf. $5 \%$ above); and (ii) coefficient $\beta_{\text {IRISH }}$ was significant at the $5 \%$ level (cf. not significant above). Re-estimation of the scaled UK model to allow for clustering by using portfolios of stocks grouped on the basis of their ex-dividend day also gave qualitatively similar results. The only difference was the intercept not being significant (cf. significant above).

${ }^{18}$ The scaled Irish model was marginally significant when estimated after excluding influential observations (refer Footnote 15 above), in particular the coefficient on the Irish 21 variable was significant at the $2.5 \%$ level.
} 
with $\mathrm{Li}$, we find that dividend yield is at its lowest when tax heterogeneity is at its highest. Li suggests that companies may have decreased their dividend yield in line with the tax changes which increased investors' preferences for capital gains. The nature of the tax heterogeneity in our study is that dividends are preferred over capital gains by some investors, hence, if managers reacted in a consistent manner to the companies in Li's study, they would have increased their dividend yield rather than decreased it. ${ }^{19}$

The results for UK resident stocks are, again, contrary to expectations. Our results, summarised in Panel B of Table 7, fail to support Hypothesis 8. Trading volume was at its highest when tax heterogeneity was at its lowest. The magnitude of the excess volume for the time periods Neither and Both are surprisingly similar for the UK and Irish resident firms - which suggests the question as to whether or not there are other reasons why trading volume around ex-dividend dates has increased.

Table 8.1 shows the number and proportion of dividend events (split by Irish versus UK resident, and by time periods) for which trading around the ex-dividend day exceeds that in the estimation period at significance levels of $50 \%, 10 \%, 5 \%, 2.5 \%$ and $1 \%$. Concentrating upon the proportion in each case where significance of $10 \%$ or less is achieved, in respect of Irish resident stocks we observe, as expected from earlier results and in line with Hypothesis 7, a rise from period Both to period Irish21 and a fall from period Irish21 to period Irish11; but an unexpected rise from period Irish11 to period Neither. None of these changes, however, is statistically significant at generally acceptable levels. In respect of UK resident stocks, we observe little difference in proportions between the different time periods, and thus have little support for Hypothesis 8 .

Propensity to capture dividends is related, in earlier work, to dividend yield (for example, Lakonishok and Vermaelen, 1986 and Bell and Jenkinson, 2002). Therefore, we consider only the half samples for which the dividend yield is greatest, in Table 8.2. For UK resident stocks, we now see, as hypothesised, a fall off in the proportion of dividend events for which there is $10 \%$ significance or less of excess trading volume around ex-dividend days - between period Both and each of periods Irish and Neither (although the drops are not significant). Comparing Table 8.1 Panel B with Table 8.2 Panel B, we observe an increase in the proportion with significant excess volume with increasing dividend yield except in time period Neither, which is as expected.

For Irish resident stocks, however, sample size considerations prevent meaningful comment upon changes in the proportion. Comparing Table 8.1 Panel A with Table 8.2 Panel A, of particular interest, however, is the fall off in the raw numbers of relatively high dividend yield dividends (i.e. top

\footnotetext{
${ }^{19}$ Increases in dividend yield may not be attractive, however, if they lead to subsequent decreases and
} 
half in terms of dividend yield) from Irish resident firms as between period Both and each of periods Irish and Neither (which may certainly, to some extent, explain the foregoing).

\subsection{Results discussion and extension}

The inference from our results that TEPIC investors did seek to capture the dividends from Irish resident companies when the rate of tax credit was $21 \%$, but not when it was $11 \%$ suggests a simple calculation of bounds for the rate of overall transactions and portfolio restructuring costs as expected by TEPIC investors in Irish resident stocks on the LSE. Consider an investor who is considering investing an amount $I$ in an Irish resident stock cum-dividend in order to capture the dividend tax credit; and assume that total expected transactions and portfolio restructuring costs are viewed by the investor as a percentage, $t$, of $I$. Then, from our finding above, we suggest:

$$
\left(\frac{I}{p} d\right) \frac{21}{79}>I t>\left(\frac{I}{p} d\right) \frac{11}{89}
$$

where $p$ represents the market price per share cum-dividend, $d$ is the rate of dividend per share; and the left-most and right-most terms of the inequality represent the value of tax credit captured for an amount $I$ invested cum-dividend where the dividend tax credit rate is, respectively, $21 \%$ and $11 \%$.

Expression (14) simplifies to:

$$
Y \frac{21}{79}>t>Y \frac{11}{89}
$$

where $Y$ represents the rate of dividend yield based on cum-dividend market price.

Expression (15) may be generalised to allow for any percentage rate of tax credit, $r$, as follows, to give a general rule, under this analysis, for expected value adding tax credit capture:

$$
Y \frac{r}{100-r}>t
$$

One implication of this expression is that investment activity undertaken in order to capture dividend tax credits be restricted to stocks with high dividend yield, consistent with the discussions and analyses of Lakonishok and Vermaelen (1986), Bell and Jenkinson (2002), and others. This,

accompanying signalling costs. 
therefore, speaks further for the results obtained above, given the heterogeneity with respect to dividend yield in each of our sub-period samples.

We turn to approximating the level of total transactions and portfolio restructuring costs implied by our data. We consider dividend events of UK and Irish resident companies during period Both together with dividend events of Irish resident companies during periods Irish 21 and Irish11 (i.e. all those events which may be subject to tax credit-related dividend capture). Dividend events where the market-adjusted DOR is less than 0.5 or greater than 1.5 are removed as outliers where non-tax credit factors are clearly at work ${ }^{20}$, leaving a sample of 471 dividend events from UK and Irish resident companies. For each dividend event in this sample, the value of yield grossed up for dividend tax credit, i.e. $Y \frac{r}{100-r}$, was calculated. The sample was then divided into two: sub-sample $A$, containing dividend events for which the grossed-up yield was greater than or equal to some value, $x$; and subsample B containing dividend events for which the grossed-up yield was less than $x$ : this for $x$ ranging from $0.5 \%$ to $4.0 \%$ in increments of $0.1 \%$ (i.e., the sample was divided int 0 two samples in 26 different ways). Given that higher DOR indicates a higher propensity to dividend capture, we consider the significance with which we may conclude that the mean DOR in sub-sample $A$ exceeds that of sub-sample $B$ over the range of $x$ (see Figure 1) and seek the value(s) of $x$ where a clear separation is apparent. From Figure 1, it is clear that there is no such significance at generally acceptable levels for values of $x$ up to and including $2.3 \%$; and that significance at generally acceptable levels appears for $x$ greater than $2.4 \%$ (with exceptions when $x$ is 3.0, 3.2 and 3.3\%). Minimum significance (at the $0.3 \%$ level) is achieved when $x$ is $2.6 \%$. Therefore, from expression (16) we conclude that overall expected transactions and portfolio adjustment costs are in the order of $2.6 \%$. This is significantly higher than the 'round trip' transactions costs suggested by James (2000); and implies that expected portfolio adjustment costs are in the order of $0.8 \%$. This is consistent with the expected costs of deviation from an otherwise optimal portfolio for the purposes of dividend (and related tax credit) capture being significant; uncertainty over ex-dividend price, and the efficacy of anti-avoidance legislation which requires a stock to be held for at least a month for dividend tax credit capture to be fully effective.

\section{Summary and conclusions}

Using both price and trading volume data, we examine the market valuation of dividends from Irish and UK resident companies listed on the London Stock Exchange and the propensity of investors to capture those dividends, over the distinct contiguous phases of a 'natural experiment' - during which

\footnotetext{
${ }^{20}$ The minimum DOR expected when abstracting from all factors other than dividend tax credit would be 0.6 (assuming the UK higher rate of personal taxation at 40\%); and the maximum DOR expected would be 1.3
} 
the availability of dividend tax credit repayment to UK pension funds and UK insurance company tax exempt pension businesses (TEPIC investors) was changed. Our samples are based on the population of all LSE-listed UK and Irish resident firms' dividend events with an ex-dividend date between 1 January 1996 and 31 December 1999, with sample reduction owing only to methodological necessity and data availability.

The Irish data confirm that TEPIC investors were, in the main, the marginal investors in Irish resident stocks around ex-dividend days where there was the entitlement to re-claim a dividend tax credit at $21 \%$ of gross dividend from such stocks, but not where the tax credit rate was either $11 \%$ or there was an entitlement to re-claim a dividend tax credit from UK resident stocks. The data in respect of UK resident companies confirms the results of Bell and Jenkinson - that the marginal investors were, in the main, TEPIC investors, and that the DOR dropped significantly following the removal of the tax credit upon UK company dividends - albeit there is some evidence of continued preference amongst investors for dividends despite the removal of the tax credit motivation. This continuing preference will reduce the effectiveness of the abolition of tax credit repayments in achieving one of its stated aims, the reduction in the pressure on companies to pay dividends to institutional shareholders. ${ }^{21}$

The results of Michaely and Vila (1996) and are also supported by data upon the UK stocks in that trading volumes were significantly higher during the period of greater tax-heterogeneity. Also, as suggested by Michaely and Vila, the extent of abnormal trading volume increases with increases in dividend yield. Trading volume analysis upon the Irish stocks, owing to sample size constraints, is able neither to confirm nor contradict the regression results.

By analysis of dividend yield and available tax credit repayment, we deduce an estimated average level for total expected transactions and portfolio restructuring costs to be in the region of $2.6 \%$ of amount invested. We also find that dividend capture is sometimes effected when it appears, under this analysis, to be not worthwhile; and, conversely, that dividend capture is sometimes foregone when it appears, under the same analysis, to be worthwhile. This is consistent with the existence of firmspecific investment considerations, and investor-specific expectations as regards increasing risks arising as a result of moving from an otherwise optimal portfolios and trading transactions costs. It is also consistent with investors maximizing after tax return, rather than on maximising specific taxation effects.

(assuming full tax credit availability to tax exempt investors). The cut offs used are slightly wider than these theoretical bounds.

${ }^{21}$ Discussions with the Chief Executive Office of a UK listed company confirm that post abolition institutional investors funds still 'state' their dividend requirements. This is particularly the case in periods of falling stock market prices when fund investors require income in the absence of significant gains. 


\section{References}

Bali, R. and Hite, G. L. (1998). 'Ex-dividend day stock price behaviour: discreteness or tax-induced clienteles?' Journal of Financial Economics, 47: 127-159.

Barclay, M.J. (1987). 'Dividends, taxes and commons stock prices. The ex-dividend behavior of common stock prices before the income tax'. Journal of Financial Economics, 19: 31-44.

Bell, L. and Jenkinson, T. (2002). 'New Evidence of the Impact of Dividend Taxation and on the Identity of the Marginal Investor'. Journal of Finance, 57: 1321-1346.

Belsley, D. A., Kuh, E. and Welsch, R. E. (1980). Regression Diagnostics: Identifying Influential Data and Sources of Collinearity. New York: John Wiley \& Sons.

Campbell, J. and Beranek, W. (1955). 'Stock price behavior on ex-dividend dates'. Journal of Finance, 10: 425-429.

Chancellor of the Exchequer (1997). Budget Speech to the House of Commons (available at http://archive.treasury.gov.uk/pub/html/budget97/speech.html).

Eades, K. M., Hess, P. and Kim, E. H. (1984). 'On interpreting security returns during ex-dividend period'. Journal of Financial Economics, 13: 3-34.

Elton, E. J. and Gruber, M. J. (1970). 'Marginal stockholder tax rates and the clientele effect'. Review of Economics and Statistics, 52: 68-74.

Fedenia, M. and Grammatikos, T. (1993). 'Risk premia and the ex-dividend stock price behavior'. Journal of Banking and Finance, 17: 575-589.

Frank, M. and Jagannathan, R. (1998). 'Why do stock prices drop by less than the value of the dividend? Evidence from a country without taxes'. Journal of Financial Economics, 47: 161-188.

James, K. R. (2000). 'The Price of Retail Investing in the UK'. Financial Services Authority: Occasional Paper Series, February.

Kaplanis, G. P. (1986). 'Options, taxes and ex-dividend day behavior'. Journal of Finance, 41: 411424.

Lasfer, M. A. (1995). 'Ex-day behavior: tax or short-term trading effects'. Journal of Finance, 50: 875-897.

Lakonsihok, J. and Vermaelen, T. (1983). 'Tax reform and ex-dividend day behavior'. Journal of Finance, 38: 1157-1179.

Lakonsihok, J. and Vermaelen, T. (1986). 'Tax-induced trading around ex-dividend days'. Journal of Financial Economics, 16: 287-319.

Li, O. Z. (2002). 'Investor tax heterogeneity and ex dividend day trading volume - the effect of dividend yield and institutional ownership'. University of Arizona Research Paper (available via http://www.ssrn.com).

Lucey, B. M. (2001). 'Preholiday Behaviour of Irish Stock Exchange Indices'. Trinity College Dublin Working Paper (available via http://www.ssrn.com).

Michaely R. and Vila, J. (1995). 'Investors heterogeneity, prices and volume around the ex-dividend day'. Journal of Financial and Quantitative Analysis, 30: 171-198.

Michaely R. and Vila, J. (1996). 'Trading volume with private valuation: Evidence from the exdividend day'. Review of Financial Studies, 9: 471-509.

Modigliani, M. and Miller, M. H. (1963). 'Corporate Income Taxes and the Cost of Capital: A Correction'. American Economic Review, 53(3), June: 433-443

Mulligan, C. (1996). 'The Irish Stock Exchange and Regulatory Change'. The Aberdeen Papers in Accountancy, Finance and Management, W15.

Nabarro Nathonson (2000). Pension Law Handbook. Tolley Publications.

Poterba, J. T. and Summers, L. H. (1984). 'New evidence that taxes affect the valuation of dividends'. Journal of Finance, 39: 1397-1415.

Rawlings, J.O. (1980), Applied Regression Analysis, Wadsworth \& Brooks, Pacific Grove, CA.

Ross, S. A. (1977). 'The Determination of Financial structure: The Incentive-Signalling Approach', Bell Journal Of Economics, Spring: 23-40.

Rozeff, M. (1982). Growth, Beta and Agency Costs as Determinates of Dividend Payout Ratios", Journal of Financial Research, June: 777-792. 
Scholes, M. and Williams, J. (1977). 'Estimating betas from non-synchronous data'. Journal of Financial Economics, 5: 309-327.

UK - Republic of Ireland Double Taxation Convention of 2 June 1976 (SI 1976/ 2151) as Amended (1976). HMSO (available via http://www.legislation.hmso.gov.uk/stat.htm).

White, H. (1980). 'A Heteroskedasticity-Consistent Covariance Matrix Estimator and a Direct Test for Heteroskedasticity’. Econometrica, 48(4): 817-838. 


\begin{tabular}{|c|c|c|}
\hline \multirow{2}{*}{\multicolumn{3}{|c|}{$\begin{array}{l}\text { Table } 1 \\
\text { Ireland and UK: tax credit rates on dividends and availability of tax credit repayment to tax exempt investors }\end{array}$}} \\
\hline & & \\
\hline \\
\hline \multirow{2}{*}{ Period } & \multicolumn{2}{|c|}{ Percentage rate of tax credit as applicable to gross dividend } \\
\hline & Republic of .Ireland & $U K$ \\
\hline $6^{\text {th }}$ April 1995 to $5^{\text {th }}$ April 1996 (inclusive) & 23 & 20 \\
\hline $6^{\text {th }}$ April 1996 to $5^{\text {th }}$ April 1997 (inclusive) & 23 & 20 \\
\hline $6^{\text {th }}$ April 1997 to $2^{\text {nd }}$ December 1997 (inclusive) & 21 & 20 \\
\hline $3^{\text {rd }}$ December 1997 to $5^{\text {th }}$ April 1998 (inclusive) & 11 & 20 \\
\hline $6^{\text {th }}$ April 1998 to $5^{\text {th }}$ April 1999 (inclusive) & 11 & 20 \\
\hline After $5^{\text {th }}$ April 1999 & 0 & 10 \\
\hline \multicolumn{3}{|c|}{ Panel B: Availability of tax credit repayment to tax exempt investors } \\
\hline UK firms' dividends & \multicolumn{2}{|c|}{$\begin{array}{l}\text { Repayment available up to and including } 1 \text { July 1997; not on or after } \\
2 \text { July } 1997\end{array}$} \\
\hline Republic of Ireland firms' dividends & \multicolumn{2}{|c|}{$\begin{array}{l}\text { Repayment available up to and including } 31 \text { December 1998; not on } \\
\text { or after 1 January } 1999\end{array}$} \\
\hline
\end{tabular}




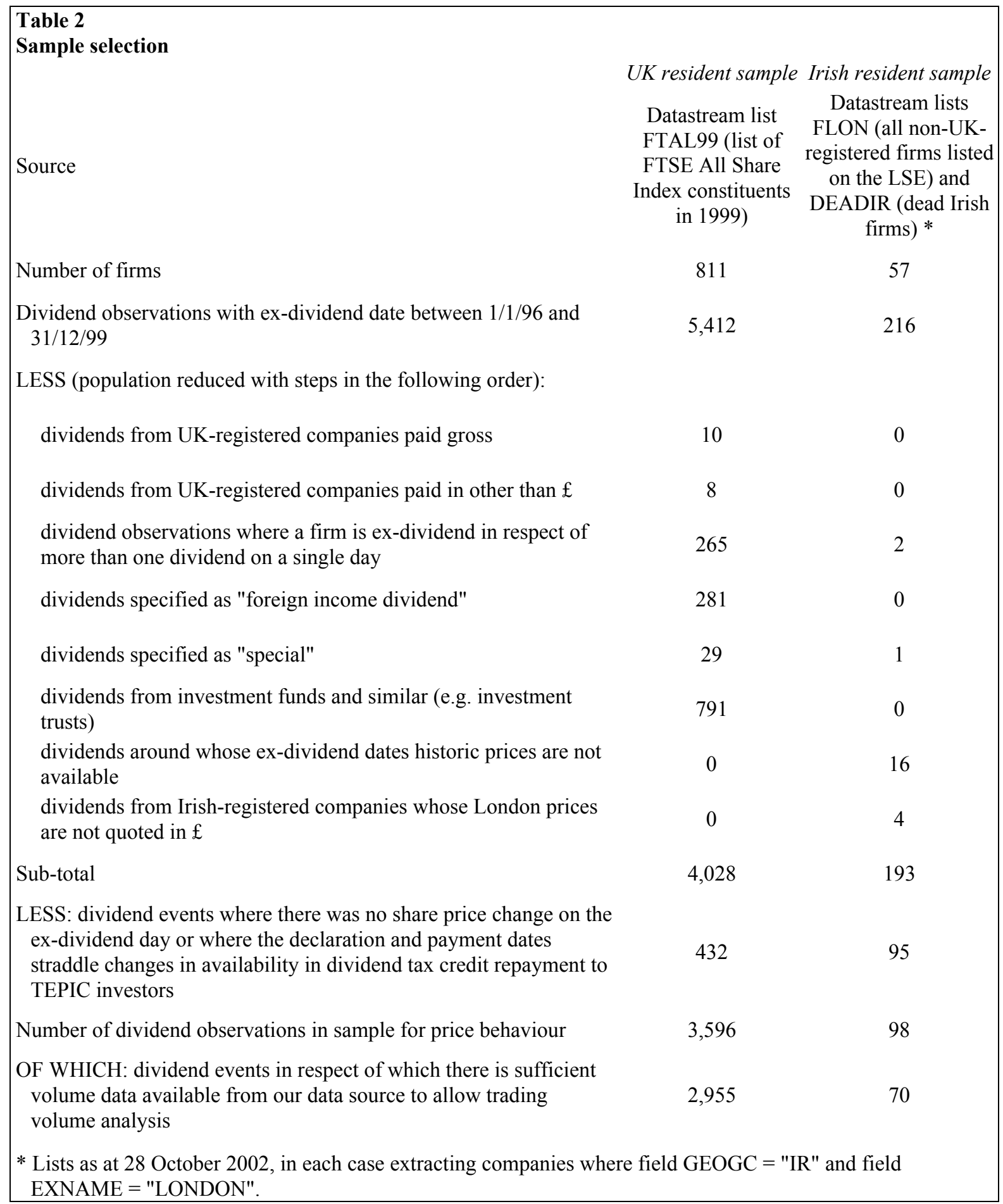




\begin{tabular}{|c|c|c|c|c|c|c|}
\hline \multicolumn{7}{|l|}{$\begin{array}{l}\text { Table } 3 \\
\text { Descriptive statistics }\end{array}$} \\
\hline \multicolumn{7}{|c|}{ Panel A: Irish stocks listed on the London Stock Exchange } \\
\hline \multirow{2}{*}{\multicolumn{2}{|c|}{$\begin{array}{l}\text { Period } \\
\text { Number of dividend events }\end{array}$}} & All & Both & Irish 21 & Irish 11 & Neither \\
\hline & & $(98)$ & $(29)$ & (8) & $(31)$ & $(30)$ \\
\hline \multirow[t]{3}{*}{ Cum-div price } & mean & 255.2 & 243.8 & 218.9 & 249.1 & 282.1 \\
\hline & median & 179.3 & 180.0 & 160.5 & 190.0 & 201.8 \\
\hline & st. dev & 191.6 & 177.2 & 181.4 & 180.1 & 222.9 \\
\hline \multirow[t]{3}{*}{ Net dividend } & mean & 2.689 & 2.827 & 1.472 & 2.389 & 3.189 \\
\hline & median & 2.223 & 2.386 & 0.932 & 1.735 & 2.610 \\
\hline & st. dev & 2.080 & 2.149 & 1.316 & 1.922 & 2.235 \\
\hline \multirow[t]{3}{*}{ Adjusted price drop } & mean & 1.663 & 1.09 & 4.82 & 0.565 & 2.512 \\
\hline & median & 1.617 & 1.11 & 4.44 & 1.697 & 1.524 \\
\hline & st. dev & 4.952 & 6.11 & 4.25 & 4.792 & 3.572 \\
\hline \multirow[t]{3}{*}{ Dividend yield } & mean & 0.012 & 0.013 & 0.007 & 0.010 & 0.014 \\
\hline & median & 0.011 & 0.012 & 0.006 & 0.009 & 0.012 \\
\hline & st. dev & 0.006 & 0.006 & 0.002 & 0.005 & 0.007 \\
\hline \multirow[t]{3}{*}{ Price drop ratio (DOR) } & mean & 0.661 & 0.152 & 3.480 & 0.177 & 0.900 \\
\hline & median & 0.765 & 0.677 & 2.390 & 0.876 & 0.623 \\
\hline & st. dev & 3.358 & 2.868 & 3.430 & 4.616 & 1.457 \\
\hline \multirow[t]{3}{*}{$\left(\mathrm{P}_{0}-\mathrm{P}_{1}\right) / \mathrm{P}_{0}$} & mean & 0.007 & 0.006 & 0.020 & 0.002 & 0.009 \\
\hline & median & 0.010 & 0.012 & 0.016 & 0.008 & 0.009 \\
\hline & st. dev & 0.025 & 0.026 & 0.022 & 0.032 & 0.014 \\
\hline \multicolumn{7}{|c|}{ Panel B: UK stocks listed on the London stock exchange } \\
\hline \multirow{2}{*}{\multicolumn{2}{|c|}{$\begin{array}{l}\text { Period } \\
\text { Number of dividend events }\end{array}$}} & All & Both & \multicolumn{2}{|c|}{ Irish } & Neither \\
\hline & & $(3596)$ & (1212) & & & (1203) \\
\hline \multirow[t]{3}{*}{ Cum-div price } & mean & 421.24 & 399.61 & & & 431.0 \\
\hline & median & 321.25 & 320.00 & & & 323.0 \\
\hline & st. dev & 391.11 & 335.06 & & & 413.6 \\
\hline \multirow[t]{3}{*}{ Net dividend } & mean & 5.332 & 5.250 & & & 5.603 \\
\hline & median & 3.900 & 3.780 & & & 4.000 \\
\hline & st. dev & 5.087 & 4.733 & & & 5.522 \\
\hline \multirow[t]{3}{*}{ Adjusted price drop } & mean & 4.236 & 4.839 & & & 3.626 \\
\hline & median & 2.978 & 3.263 & & & 2.734 \\
\hline & st. dev & 14.595 & 13.881 & & & 15.204 \\
\hline \multirow[t]{3}{*}{ Dividend yield } & mean & 0.015 & 0.015 & & & 0.016 \\
\hline & median & 0.013 & 0.013 & & & 0.013 \\
\hline & st. dev & 0.011 & 0.008 & & & 0.015 \\
\hline \multirow[t]{2}{*}{ Price drop ratio (DOR) } & mean & 0.657 & 0.774 & & & 0.435 \\
\hline & median & 0.873 & 0.920 & & & 0.823 \\
\hline \multirow{4}{*}{$\left(\mathrm{P}_{0}-\mathrm{P}_{1}\right) / \mathrm{P}_{0}$} & st. dev & 4.850 & 2.437 & & & 5.487 \\
\hline & mean & 0.012 & 0.012 & & & 0.011 \\
\hline & median & 0.012 & 0.012 & & & 0.011 \\
\hline & st. dev & 0.024 & 0.021 & & & 0.026 \\
\hline
\end{tabular}




\section{Table 4}

Significance of difference between the drop-off ratio as between subperiod samples

Panel A: Irish stocks listed on the London stock exchange

$$
\text { t-statistic Wilcoxon Mann }
$$

Irish 21 with Both

(1-tail)

$2.52 * *$

Whitney sig. level

Irish 11 with Both

(2-tail)

0.003

0.801

(2-tail)

0.03

0.994

$0.014 *$

Irish 11 with Irish 21

Neither with Irish21

(1-tail)

1.26

$-2.25 *$

(1-tail)

$-2.08$

0.005

Neither with Irish 11

(2-tail)

0.83

0.846

Panel B: UK stocks listed on the London stock exchange

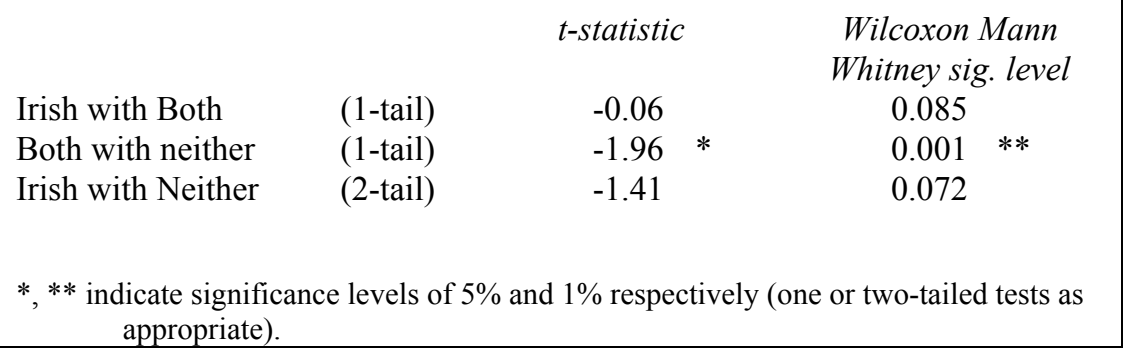




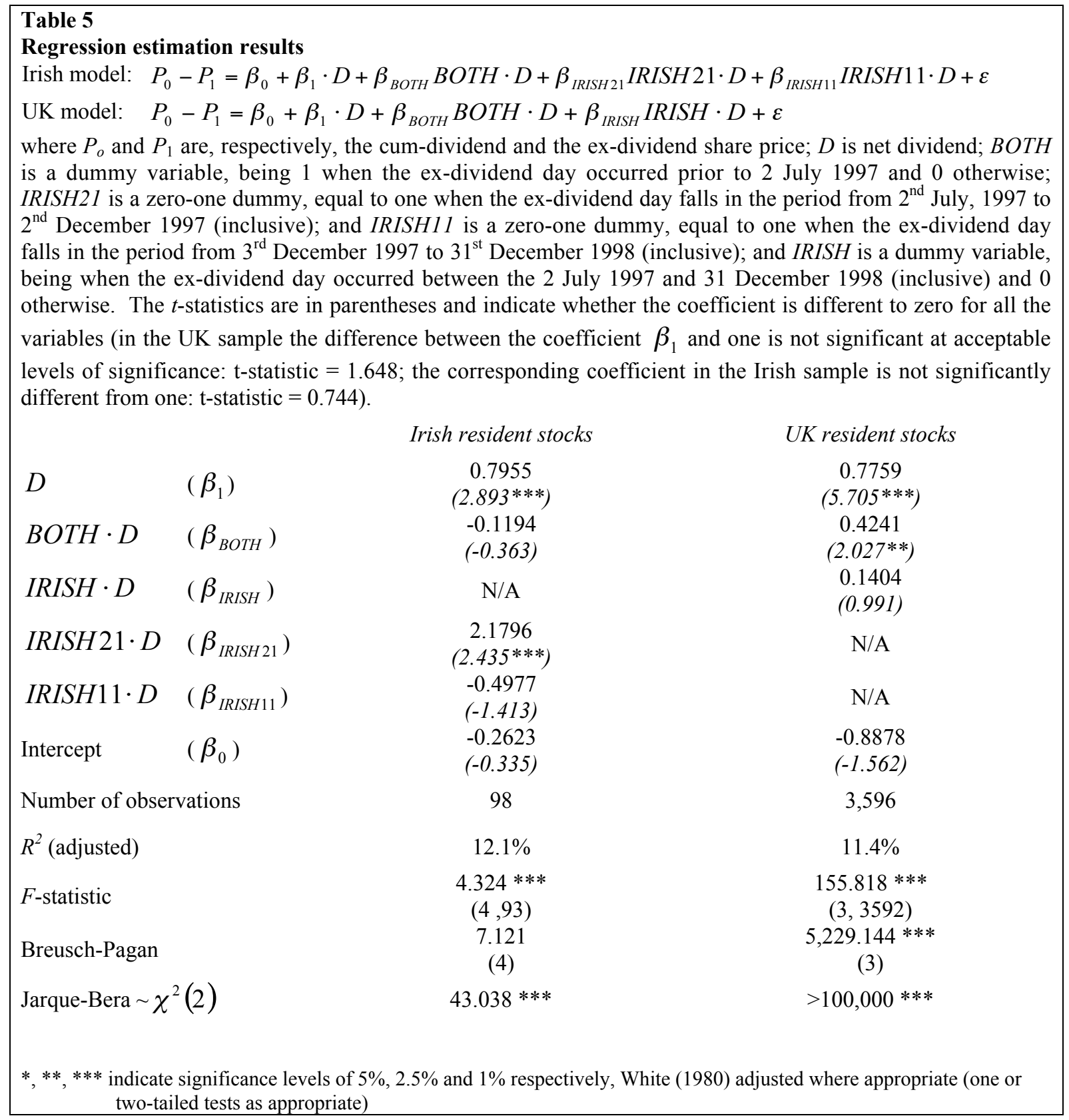




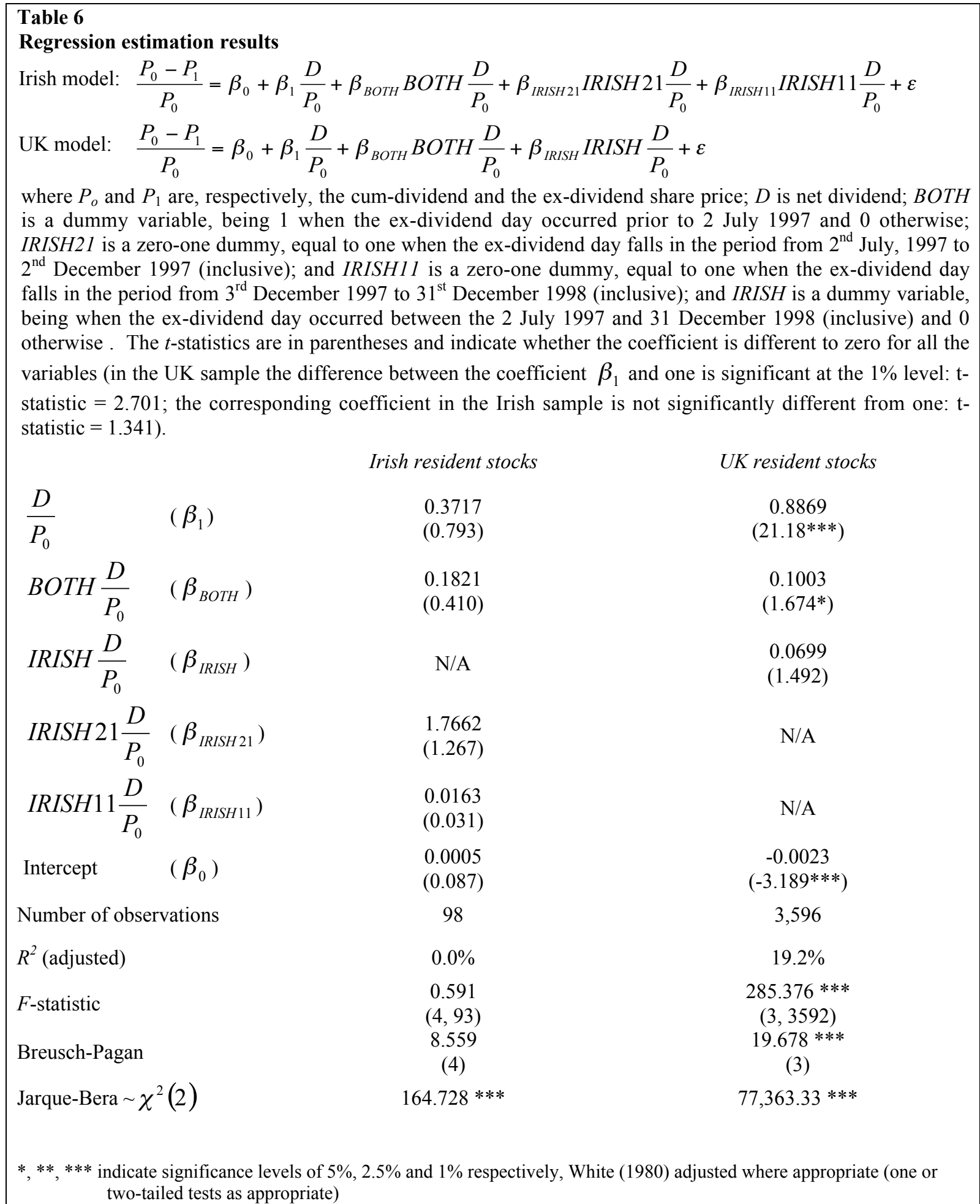




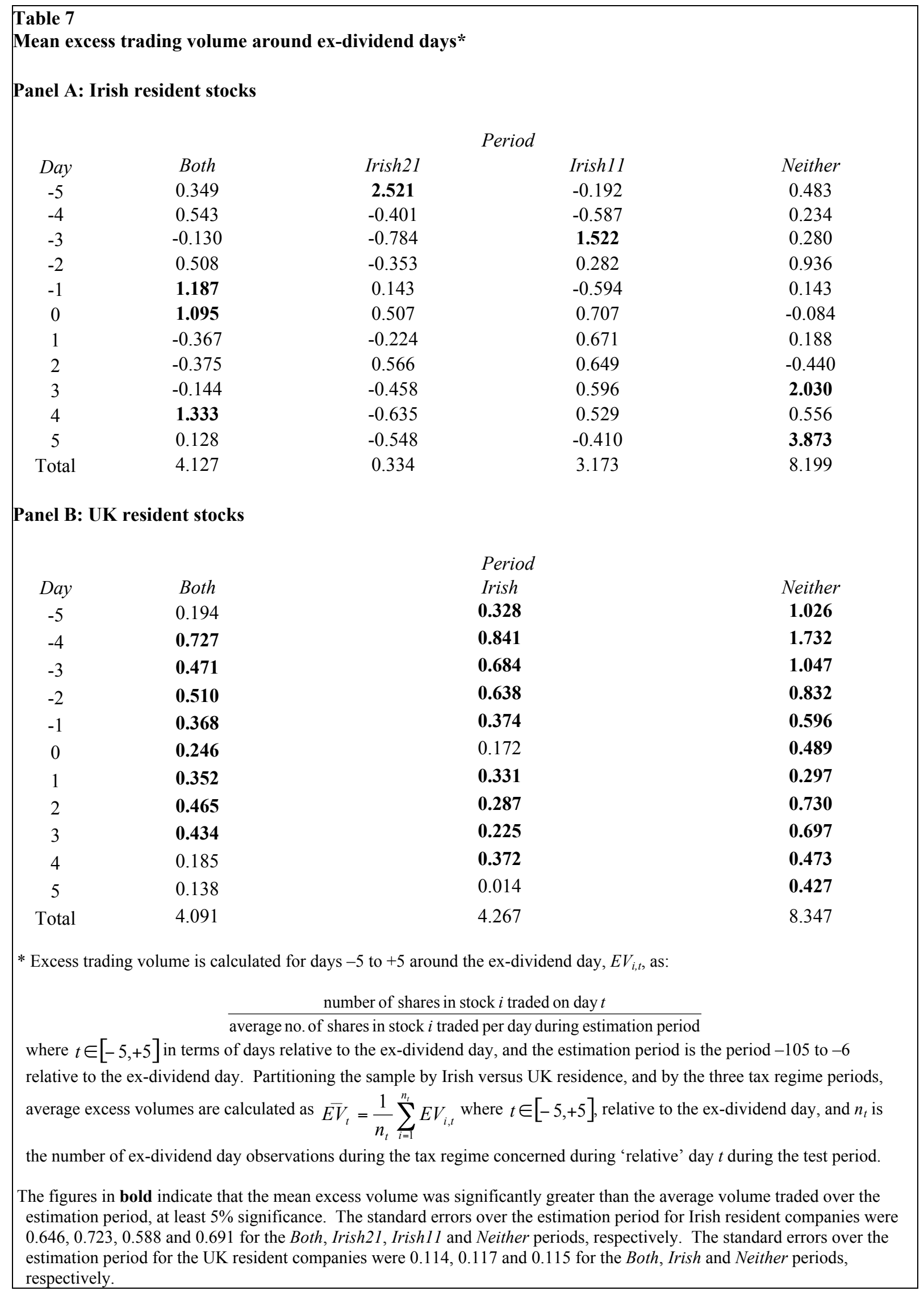




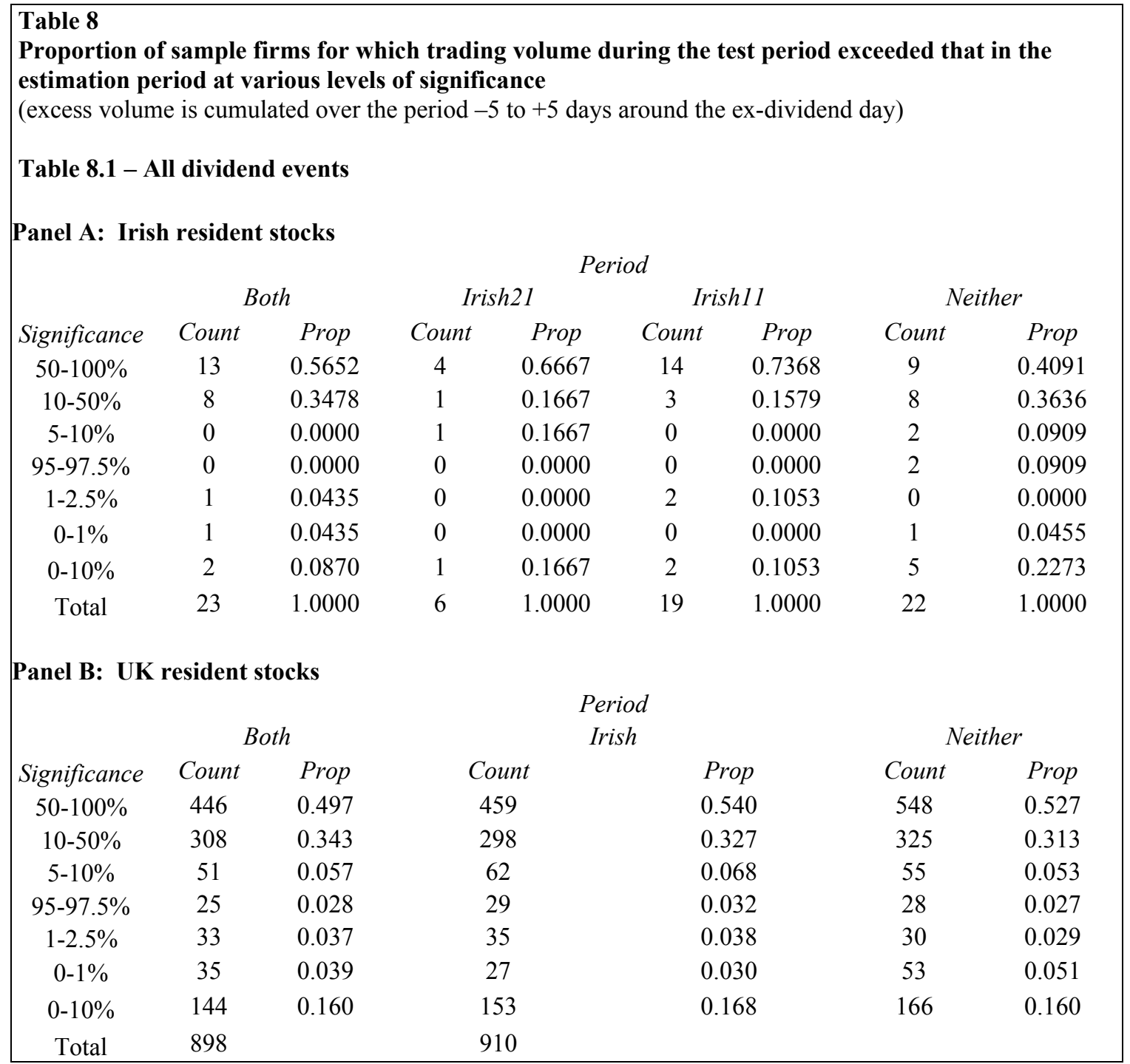




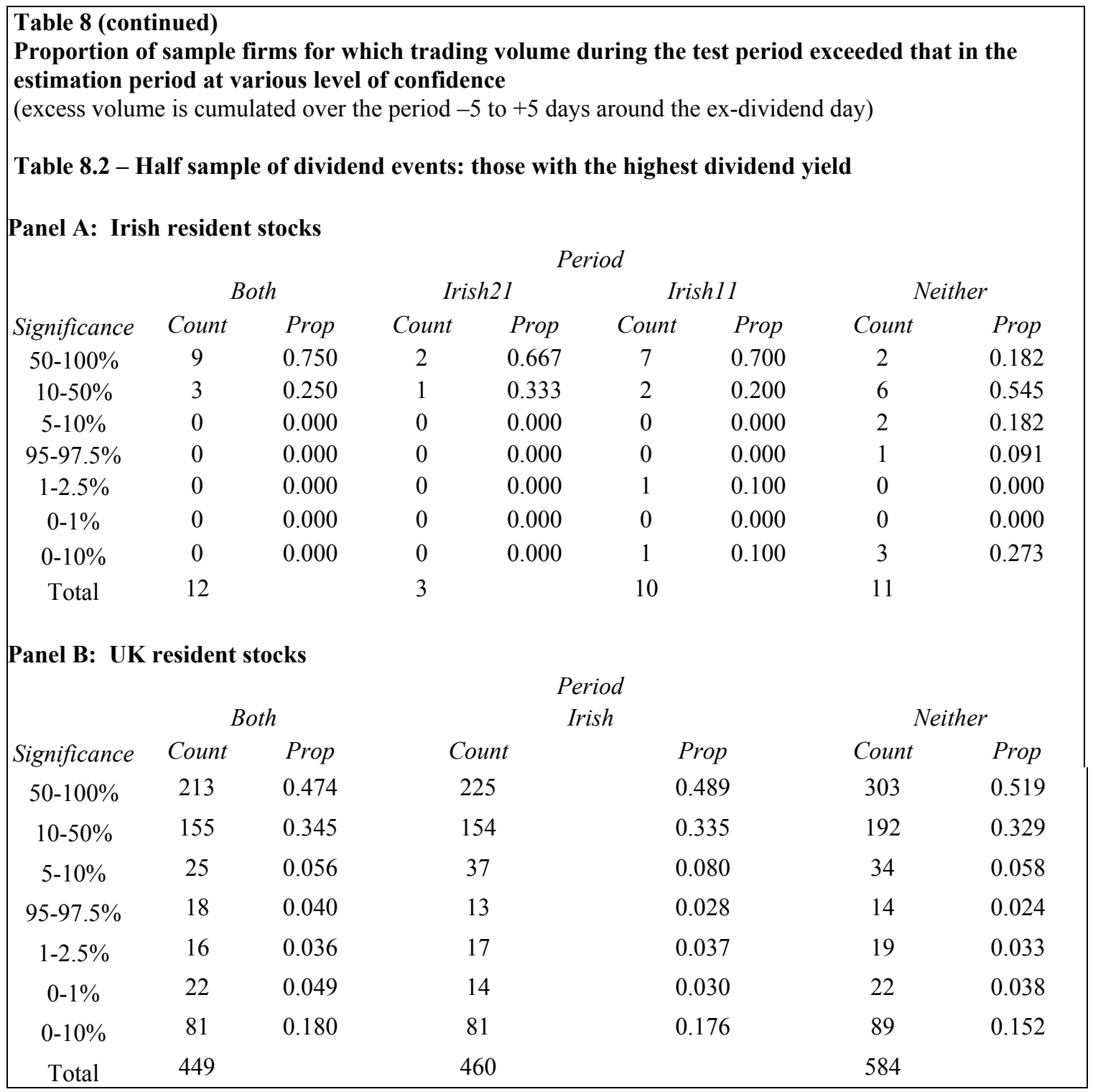




\section{Figure 1}

Sample divided into two sub-samples, each dividend event being assigned to sub-sample $A$ if $Y r /(100-r)$ is greater than $\boldsymbol{x}$, and to sub-sample $\boldsymbol{B}$ if this quantity is less than $\boldsymbol{x}$ : significance with which the hypothesis that the mean DOR for sub-sample $A$ is greater than that for sub-sample $B$ for various values of $x$

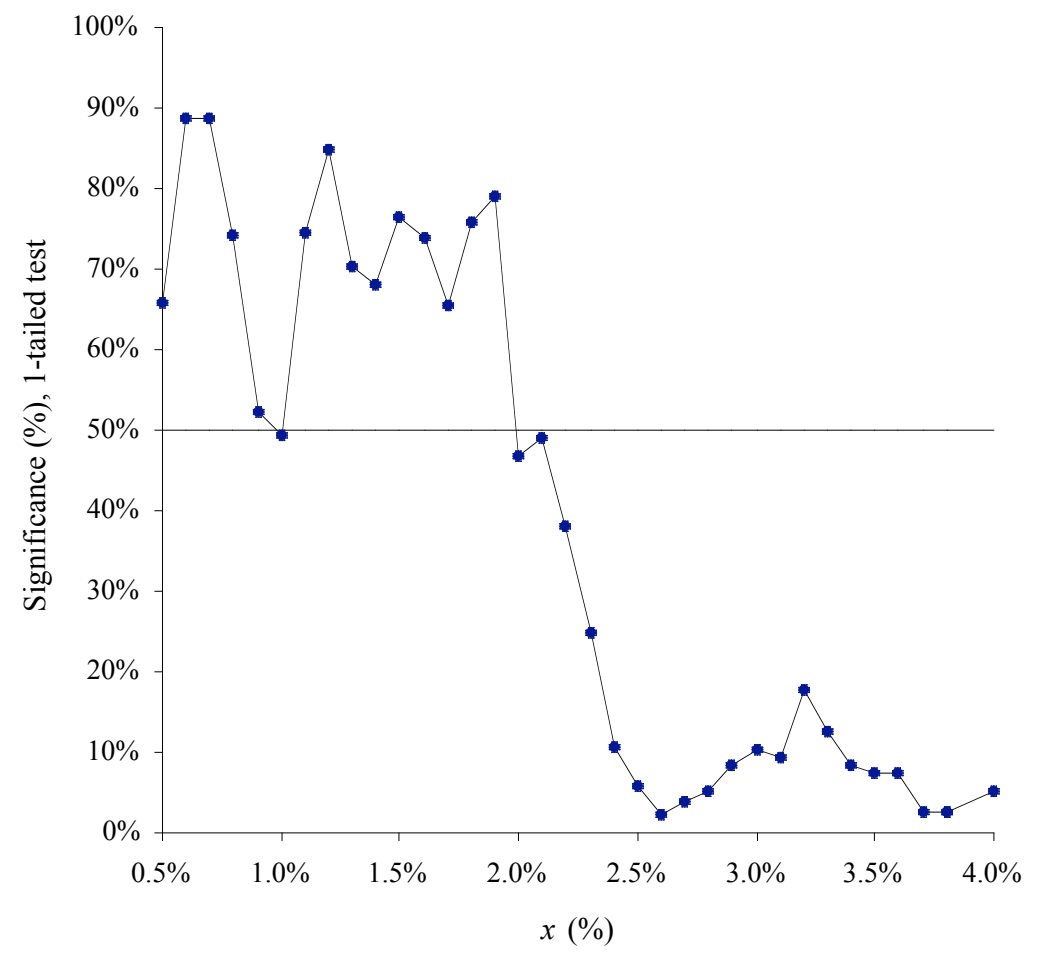

